\title{
Combining data from different sampling methods to study the development of an alien crab Chionoecetes opilio invasion in the remote and pristine Arctic Kara Sea
}

\author{
Anna K Zalota ${ }^{\text {Corresp., } 1}$, Olga L Zimina ${ }^{2}$, Vassily A Spiridonov ${ }^{1}$ \\ ${ }^{1}$ Shirshov Institute of Oceanology, Russian Academy of Sciences (SIO RAS), Moscow, Russia \\ 2 Murmansk Marine Biological Institute KSC, Russian Academy of Sciences (MMBI KSC RAS), Murmansk, Russia \\ Corresponding Author: Anna K Zalota \\ Email address: azalota@gmail.com
}

Data obtained using three different sampling gear is compared and combined to assess the size composition and density of a non-indigenous snow crab population Chionoecetes opilio in the previously free of alien species Kara Sea benthos. The Sigsbee trawl has small mesh and catches even recently settled crabs. The large bottom trawl is able to catch large crabs, but does not retain younger crabs, due to its large mesh. Video sampling allows observing larger crabs although some smaller crabs can also be spotted. The combined use of such gear could provide full scope data of the existing size groups in a population.

The density of the crabs was calculated from the video footage. The highest figures were in Blagopoluchiya Bay at $0.87 \mathrm{crabs} / \mathrm{m}^{2}$, where the settlement seems to reach its first peak of population growth after the introduction. High density in the Kara Gates Strait at $0.55 \mathrm{crabs} / \mathrm{m}^{2}$, could be due to the close proximity of the Barents Sea from where the crabs can enter by both larvae dispersal and active adult migration. All size groups have been present in most sampled areas, which suggest successful settlement and growth of crabs over a number of years. Again, this was not the case in Blagopoluchiya Bay with high density of small crabs ( $<30 \mathrm{~mm} \mathrm{CW}$ ), which confirms its recent population growth. Male to female ratio was strikingly different between the bays of the Novaya Zemlya Archipelago and west of the Yamal Peninsula (0.8 and 3.8 respectively). Seventy five ovigerous females were caught in 2016, which confirms the presence of a reproducing population in the Kara Sea.

The spatial structure of the snow crab population in the Kara Sea is still in the process of formation. The presented data indicates that this process may lead to a complex system, which is based on local recruitment and transport of larvae from the Barents Sea and across the western Kara shelf; formation of nursery grounds; active migration of adults and their concentration in the areas of the shelf with appropriate feeding conditions. 

alien crab Chionoecetes opilio invasion in the remote and pristine Arctic Kara Sea

\section{3}

Corresponding Author:

Anna Zalota

36 Nakhimovskiy pr., Moscow, 117997, Russia

Email address: azalota@gmail.com

17

8

9

size composition and density of a non-indigenous snow crab population Chionoecetes opilio in the previously free of alien species Kara Sea benthos. The Sigsbee trawl has small mesh and catches even recently settled crabs. The large bottom trawl is able to catch large crabs, but does not retain younger crabs, due to its large mesh. Video sampling allows observing larger crabs although some smaller crabs can also be spotted. The combined use of such gear could provide full scope data of the existing size groups in a population.

The density of the crabs was calculated from the video footage. The highest figures were in Blagopoluchiya Bay at $0.87 \mathrm{crabs} / \mathrm{m}^{2}$, where the settlement seems to reach its first peak of population growth after the introduction. High density in the Kara Gates Strait at $0.55 \mathrm{crabs} / \mathrm{m}^{2}$, could be due to the close proximity of the Barents Sea from where the crabs can enter by both larvae dispersal and active adult migration. All size groups have been present in most sampled areas, which suggest successful settlement and growth of crabs over a number of years. Again, this was not the case in Blagopoluchiya Bay with high density of small crabs $(<30 \mathrm{~mm} \mathrm{CW})$, 
32 which confirms its recent population growth. Male to female ratio was strikingly different 33 between the bays of the Novaya Zemlya Archipelago and west of the Yamal Peninsula ( 0.8 and 343.8 respectively). Seventy five ovigerous females were caught in 2016, which confirms the 35 presence of a reproducing population in the Kara Sea.

36 The spatial structure of the snow crab population in the Kara Sea is still in the process of 37 formation. The presented data indicates that this process may lead to a complex system, which is 38 based on local recruitment and transport of larvae from the Barents Sea and across the western 39 Kara shelf; formation of nursery grounds; active migration of adults and their concentration in 40 the areas of the shelf with appropriate feeding conditions. 
43

44

45

46

47

48

49

50

51

52

53

54

55

56

57

58

59

60

61

62

63

64

65

66

67

68

69

70 71 eastward to the Beaufort Sea (Slizkin et al., 2007; Sirenko \& Vassilenko, 2008). There is only one 72 record of snow crabs on the border between the East Siberian and the Laptev Seas, off the New

\section{INTRODUCTION}

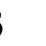

4

The process of a non-indigenous species (NIS) invasion can take a long time (Byers et al., 2015) and often remains incompletely observed. An ongoing invasion of a large predatory snow crab, Chionoecetes opilio, into the previously pristine Kara Sea benthic environment is an exceptional opportunity for researchers as a rapid and observable from its starting point process (Zalota et al., 2018). Due to the changing climate, and the current reduction of sea ice cover in the Arctic, it is widely expected that the shipping and other human activity will greatly increase (Ho, 2010; Liua and Kronbak, 2010). Such productive and important for fishery seas as the Bering and the Barents Seas are well studied and have ongoing large scientific projects to study their populations of snow crabs, such as joint Russian-Norwegian studies of the Barents Sea (Pavlov \& Sundet, 2011; Hammer \& Hoel, 2012; Jørgensen et al., 2015; Sokolov et al., 2016).

This is not the case for the Siberian seas that have lower productivity, and until recently had very short ice-free seasons (Zenkevich, 1963; Vinogradov et al., 2000; AARI, 2009; Demidov \& Mosharov, 2015). Biological research in the Kara Sea benthos is mostly conducted by occasional expeditions of the Shirshov Institute of Oceanology, Russian Academy of Sciences (SIO), Murmansk Marine Biological Institute, Russian Academy of Sciences (MMBI) and the Knipovich Polar Institute of Fishery and Oceanography (PINRO) (Jørgensen et al., 1999; Sokolov et al., 2016). The intensity and area of sampling effort varies, and so does the sampling gear employed. Therefore, it is important to compare and understand the differences in the results obtained by different gear to be able to gather informative data on the new snow crab population.

The snow crab, Chionoecetes opilio (Decapoda: Oregonidae) has invaded vast areas of the Barents and Kara seas with an unprecedented speed for a shelf species (Pavlov, 2006; Pavlov \& Sundet, 2011; Zimina, 2014; Bakanev, 2015; Sokolov et al., 2016; Spiridonov \& Zalota, 2017;

67 Zalota et al., 2018). The native range of this species covers the North-Western Atlantic

8 (Newfoundland and Labrador waters, south-west Greenland shelf to southern Baffin Bay)

69 (Squires, 1990); the North Pacific northwards of the Aleutian Islands and the Sea of Japan

70 (Slizkin, 1982), and the Chukchi Sea westward to the boundary with the East Siberian Sea and 
73 Siberian Islands (Sokolov et al., 2009). Ch. opilio is an active benthic predator consuming a

74 broad range of invertebrates, and even fish (Tarverdieva, 1981; Chuchukalo et al., 2011;

75

76

77

78

79

80

81

82

83

84

85

86

87

88

89

90

91

92

93

94

95

96

97

98

99

100

101

102

Lovvorn, 2010; Kolts et al., 2013; Zalota, 2017; Zakharov et al., 2018).

The first record of snow crab in the Barents Sea was in 1996 (Kuzmin et al., 1998). It is possible that the introduction took place between the mid-1980s and 1993 (Alvsvaig et al., 2009; Strelkova, 2016). By the mid-2010s the snow crabs occupied the entire central, eastern, and most of the northern part of the Barents Sea. Uncontrolled snow crab fishery commenced in 2013 in the international fishery enclave between the EEZs of Russia and Norway and in the Spitsbergen fishery protection zone (Bakanev et al., 2017; Sundet \& Bakanev, 2014). A regulated snow crab fishery in Russia's EEZ of the Barents Sea began in 2016 (Bakanev et al., 2016).

The snow crab population grew in the Barents Sea and expanded towards the Kara Sea. The first crabs were found on the boundary of the two seas in 2008 (Strelkova, 2016), then in the north-west of the Kara Sea in 2010 and 2011 (Strelkova, 2016; Zalota et al., 2018). Both adults and larvae were caught in the south-western Kara Sea in 2012 (Zimina, 2014). In less than five years after the initial records, Ch. opilio was observed over the entire western Kara Sea shelf (Zalota et al., 2018). A high abundance of adult snow crabs was recorded in 2013 in the southwestern Kara Sea, between the Yamal Peninsula and the Kara Gate Strait, which is the entrance from the Barents Sea (Strelkova, 2016). In 2014, several size groups of juveniles were present throughout the western shelf and the fjords of the eastern Novaya Zemlya Archipelago, with the most numerous groups presumably originating from larval settling in 2013 (Zalota et al., 2018). It is still uncertain if the Kara snow crab population is fully established and independent of the import of larvae and adult migration from the Barents Sea, and how far it can expand eastwards.

The oceanographic conditions of the Kara Sea are very different from the Barents Sea. The western Kara Sea is strongly influenced by the water exchange with the Barents Sea and by the advection of fresh water from large Siberian rivers' runoff (Pavlov \& Pfirman, 1995; Zatsepin et al., 2010a; Zatsepin et al., 2010b; Zatsepin et al., 2015; Polukhin \& Zagretdinova, 2016). The Kara Sea is covered with ice for most of the year, with extensive fast ice massifs and regular polynya formations (Gavrilo \& Popov, 2011; Polukhin \& Zagretdinova, 2016).

Beginning from the mid-2000s, the Kara Sea follows a general Arctic trend of delaying sea ice formation in autumn and earlier decay in spring/early summer (Ashik et al., 2014). This

Peer) reviewing PDF | (2019:04:36317:2:0:NEW 21 Sep 2019) 
103 coincided with the commencement of Ch. opilio invasion from the Barents Sea (Zalota et al., 104 2018).

105 In comparison to the Barents Sea, the Kara Sea has a much lower primary productivity 106 (Vinogradov et al., 2000; Romankevich \& Vetrov, 2001; Demidov \& Mosharov, 2015; Demidov 107 et al., 2015) and benthic biomass (Zenkevich, 1963; Denisenko et al., 2003; Kulakov et al., 2004;

108 Udalov et al., 2016; Chava et al., 2017). Its ecosystem is noticeably affected by climate change 109 and the lengthening of ice-free season (Ashik et al., 2014). Persistent accumulation of organic 110 pollution (AMAP Assessment, 2015) and a massive offshore and coastal oil and gas development, 111 and shipping (Amiragyan, 2017) will influence the Kara Sea in the nearest future. The 112 establishment of a breeding snow crab population, even if itremains dependent on the Barents 113 Sea stock, may have additional large scale impact on the distinct Kara Sea ecosystem. On the 114 other hand, the snow crabs could potentially grow to the commercial size and become a target for 115 a regulated offshore fishery, which has never existed in the Kara Sea before. It is therefore 116 critical to study the development of the snow crab population in the Kara Sea to forecast the

117 future of the Siberian Shelf ecosystems, and the options for resource management and 118 biodiversity conservation.

119 The Barents Sea snow crab population is spatially and temporally monitored in a 120 standardized way (Jørgensen et al., 2015; Strelkova, 2016). Due to its limited fishery resources, 121 the Kara Sea is less visited and surveyed using standard fishery trawls, which makes it very 122 difficult to obtain a representative samples of adult snow crabs and to monitor their abundance 123 (Zimina et al., 2015; Sokolov et al., 2016). Since 2007, smaller scientific gear, such as Sigsbee 124 trawls, has been used in regular expeditions of the SIO to the Kara Sea. It provides a good 125 representation of juvenile groups, but most likely underestimates large crabs (Zalota et al., 126 2018). Therefore, to study the population of snow crabs in the Kara and potentially in other 127 Siberian seas in the long term, we need to learn how to combine the data supplied by different 128 gear to draw meaningful conclusions and obtain data any time there is an opportunity 129 In the summer season of 2016 we employed three methods to study snow crab size 130 composition and abundance: Sigsbee trawl, video transects; and a large Campelen-type bottom 131 trawl. The video survey is-_a non-destructive for seabed, less costly and less labor intensive 132 method of rapid assessment of the density and size structure of crabs' settlements. However, the 
133 video data lacks important information, such as differences in size composition related to sex

134 ratio. Therefore, it is important to identify the information that can be safely combined.

135 The purpose of the present paper is to compare and understand the differences in the

136 results obtained by different gear to study an ongoing invasion of an alien crab in the remote

137 Kara Sea. The data from three types of sampling gear is analyzed to obtain the size and sex

138 composition, and the density of snow crab settlements in the Kara Sea in 2016. By identifying

139 specifics and merging the results obtained by these different gear we aim to assess the progress

140 of the Ch. opilio invasion in the Kara Sea, and to compare it with earlier stages (2008 - 2014)

141 described by Zimina (2014), Strelkova (2016) and Zalota et al. (2018).

142

MATERIAL AND METHODS

The crabs Chionoecetes opilio were studied using three sampling methods, during the cruises of the Research Vessel Dalniye Zelentsy (MMBI) and the RV Akademik Mstislav Keldysh (SIO), in August-September 2016. MMBI samples were collected using a Campelen-type bottom trawl with a $20 \mathrm{~m}$ horizontal by an 8-10 m vertical opening, equipped with a double net; the outer net with $135 \mathrm{~mm}$ mesh and lower insertion of the net with $12 \mathrm{~mm}$ mesh. The SIO samples were collected using a Sigsbee trawl with a steel frame of $2 \mathrm{~m}$ breadth and $35 \mathrm{~cm}$ height. The trawl was equipped with a double net; the outer net had $45 \mathrm{~mm}$ mesh and inner net had $4 \mathrm{~mm}$ mesh.

A video transect was filmed by the SIO team of engineering and technical research in combination with four trawlings (Fig. 1). This was done using an uninhabited, towed, submerged, inert vehicle (UTSI) Video Module (Pronin, 2017), equipped with a control and data transmission system through which information is received and control commands are transferred via an optical cable in real time. UTSI Video Module has a navigation system, power supply, three video cameras (one of them is of high resolution, set up to carry out planimetric surveys), six floodlight projectors and two laser scale indicators, with a known distance between them $(60 \mathrm{~cm})$. The use of UTSI Video Module allowed us to obtain geo-referenced (including depth), spatially oriented and scaled images of the bottom with organisms. as MMBI samples) on the west side of the Yamal Peninsula in the Kara Sea (Fig. 1, circles.). The 
164 vicinity of four Novaya Zemlya Archipelago bays and two in the area of the Kara Gates Strait

165 (Fig. 1, diamonds). The video transects (further referred as video samples) were done prior to 166 trawling at four of these stations (Fig. 1, stars in the diamonds), and in the vicinity of Tsivolka

167 Bay without a trawling sample (Fig. 1, black star). The trawling stations of SIO closely followed the rout of the video transects and can therefore be directly compared. Both, video and trawling sampling was done in the vicinity of Blagopoluchiya, Haug, and Abrosimov bays, as well as in the southern region of the Kara Gates Strait (further referred to as Gates 2) (Fig. 1).

All crabs caught in trawls were sexed, based on visual characteristics, and measured (carapace width, CW) using a calliper to the nearest millimeter onboard the vessels. In this

173 studycrabs with CW less than $11 \mathrm{~mm}$, whose sex cannot be easily identified by visual inspection, 174 are referred to as the "juveniles". The videos were viewed using the Media Player Classic -

175 Home Cinema program in full screen mode. Manually, by screenshots, the videos were divided

176 into still frames according to the changes in the bottom features to account for varying speed of

177 towing, changing depth, and magnification. The height and width of the frame, the distance

178 between two laser points and the carapace width $(\mathrm{CW})$ of crabs present on the image were

179 measured using a ruler. All frame measurements were converted to the actual dimensions

180 considering that the distance between the laser points on the bottom was $60 \mathrm{~cm}$.

181 No native crabs, Hyas araneus, were spotted in these videos. However, in the videos

182 taken in other years (not discussed in this work) the native crabs could be successfully

183 differentiated from the snow crabs opilio in the vicinity of the Kara Gate Strait. Each video

184 frame was visually inspected by one person (A. Zalota). This was done to minimize the errors

185 related to different interpretations by various observers, which are unavoidable in such a

186 subjective analysis.. The frames where the viewer could not identify organisms easily were not

187 used. This happened when the video module was raised too high over the sea floor (due to 188 waves), but subject to visibility. Not all measured crabs were used in the density calculations,

189 since some frames had to be cut around the edges to standardize the method of area calculations

190 (in cases where the camera zoomed out and a circular lens was visible on the frame).

$191 \quad$ Most of statistical calculations and analyses were performed using RStudio (RStudio

192 Team, 2016; R Core Team, 2018). Size structure of collected crabs was analyzed using mixture

193 model analysis in PAST software (Hammer, 2013). The best fit models were selected using the

194 Akaike (Akaike, 1974) and log likelihood criteria. To analyze possible trends of crabs'size 
195 distribution in space, we looked at the correlation between the depth of sampling stations and 196 different statistical parameters of the CW. Correlations were calculated using Microsoft Excel 197 package.

198

199

200

201

202

203

204

205

206

207

208

209

210

211

212

213

214

215

216

217

218

219

220

221

222

223

224

\section{RESULTS}

Overall, the data was collected from 64 sample stations. MMBI trawled at 53 stations and caught 662 crabs; SIO caught 857 from 6 trawling stations and 884 crabs were caught on camera at the 5 stations where Video Module was employed (Fig.1). In total 2402 crabs were measured, which includes 1520 crabs caught in trawls.

\section{Size composition revealed by different sampling methods}

Different methods of collection yielded diverse size distribution of crabs. Although the size composition of adult male and female snow crabs usually differs, we discuss their aggregate composition in order to compare the data from trawling with the video data, for which no sex differentiation is possible. The carapace width $(\mathrm{CW})$ of crabs caught during SIO trawling ranged from 4 to $117 \mathrm{~mm}$ (Fig. 2 A). Mixture analysis of CWs identified 9 distinct size groups from the bulk of SIO crabs ( 7 groups from the analysis and 2 were added manually to decrease noise during the analysis) (Table 1). The majority of crabs were of small size, with CW mode at 14 $\mathrm{mm}$ (while the mean was $16 \mathrm{~mm}$ ) and another abundant group at $\mathrm{CW} 10 \mathrm{~mm}$.

The mixture analysis of crabs caught by MMBI trawling resulted in only 5 size groups (1 of which was added manually) (Table 1). Overall, crabs caught by this method were of larger size, with the minimum carapace width of $22 \mathrm{~mm}$ and the maximum of $120 \mathrm{~mm}$. A large portion of crabs was within the $52 \mathrm{~mm}$ size group (mean was $57 \mathrm{~mm}$ ) (Fig. $2 \mathrm{~B}$ ). The analysis merged smaller crabs into one group with large standard deviation $(36 \pm 7 \mathrm{~mm})$. However, the mixture analysis identified more distinct large size groups (over $52 \mathrm{~mm}$ ) in MMBI samples, than from SIO trawling and video sampling.

The smallest crab identified on the video had $7 \mathrm{~mm} \mathrm{CW}$ and the largest $127 \mathrm{~mm}$. Mixture analysis yielded 4 size groups for this method (Table 1). Most frequently crabs were within two broad size groups with CW $15 \pm 3 \mathrm{~mm}$ and $46 \pm 11 \mathrm{~mm}$ (Fig. $2 \mathrm{C}$ ). The mode CW was $15 \mathrm{~mm}$, however for this method the mean CW differed at $32 \mathrm{~mm}$. 
The boxes in Figure 2 (interquartile range containing $50 \%$ of the data) of Blagopoluchiya

226

227

228

229

230

231

232

233

234

235

236

237

238

239

240

241

242

243

244

245

246

247

248

249

250

251

252

253

254

255

Bay are very similar for both methods, and include CW below $20 \mathrm{~mm}$. The mode, median and means for the trawling and video samplings in Blagopoluchiya Bay are also very similar (Table 2). However, the maximum size observed in video $(50 \mathrm{~mm})$ was larger than in the Sigsbee trawling sample $(38 \mathrm{~mm})$, while the minimum was very similar (7 and $8 \mathrm{~mm}$ respectively). Both methods yielded large number of crabs: 735 by trawling and 388 caught on video. The SIO trawling sample revealed more distinct and sharp size groups than the video sample (Fig. 3). However, the mixture analysis identified only one additional size group in the SIO trawling sample (Table 1).

The two methods had similar results for the south of the Kara Gates Strait (Gates 2, Fig. 4; Table 2). The central 50\% of crabs had CW between 43 and $57 \mathrm{~mm}$. Trawl sampling collected 20 crabs, and we observed 186 crabs on the video. While the minimum $\mathrm{CW}$ of crabs from trawling and video were very similar, 27 and $22 \mathrm{~mm}$ respectively, the video detected much larger crabs $(127 \mathrm{~mm})$ than the trawling $(71 \mathrm{~mm})$. However, we caught large crabs (up to $117 \mathrm{~mm}$ ) while trawling in the nearby location (Gates 1, 2, Figs. 1, 4, Table 2).

We detected a very low number of crabs in Haug Bay using both methods (4 and 7 respectively). However, their sizes were very different. In trawl sample all crabs were 15-16 mm; in the video sample the sizes ranged from 27 to $50 \mathrm{~mm}$, while the majority was within 42-47 $\mathrm{mm}$.

The most distinct difference was observed in Abrosimov Bay (Fig. 4 A, B, Table 2). A large proportion of the trawl catch were small crabs (minimum and mode at $4 \mathrm{~mm} \mathrm{CW}$ ), and the central half of crabs were between 4 and $32 \mathrm{~mm}$. On the video we could observe only larger crabs (minimum $9 \mathrm{~mm}$ ), and the central half of the crabs were much larger, between 34 and 48 $\mathrm{mm}$. The largest crabs in both methods were very similar (50 mm trawling, 58 video). We measured twice as many crabs (88) on the video than in the trawling sample (43).

Sedov and Tsivolka Bays were sampled using different methods and cannot be compared directly. Trawling sample in Sedov Bay brought 28 crabs with $45 \mathrm{~mm}$ maximum and $10 \mathrm{~mm}$ minimum CW. On the Tsivolka Bay video we identified 215 crabs from 9 to $58 \mathrm{~mm} \mathrm{CW}$.

At the $53 \mathrm{MMBI}$ trawling stations the minimum $\mathrm{CW}$ ranged from 22 to 72 , and the maximum from 39 to 120 . The modes and means ranged from 32 to 94 and 34 to 75 respectively. Most often, the minimum CW was $47 \mathrm{~mm}$, maximum was $57 \mathrm{~mm}$; mode and mean were $52 \mathrm{~mm}$. 
256 Two to sixty one crabs were caught at the MMBI sampling stations, most commonly 3 crabs per 257 station, but 12 crabs on average.

258

259

260

261

262

263

264

265

266

267

268

269

270

271

272

273

274

275

276

277

278

279

280

281

282

283

284

285

286

At the $53 \mathrm{MMBI}$ trawling stations, the maximum, mode and mean CW sizes only weakly correlated with the depth (Table 3). In both SIO trawling and video samples the maximum $\mathrm{CW}$ sizes had strong correlation with the depth, although the sample size was very small.

When we mapped the maximum CW size for each station, we observed a trend in the MMBI samples, where larger crabs tend to be found in the south and northwards along the Yamal Peninsula. Towards the center of the western Kara Sea the maximum CW of the crabs decreases (Fig. 5). Similar mapping of ovigerous female findings did not show any observable trends.

\section{Sex ratio and sex related differences in size composition}

Trawling allowed identifying and comparing crabs of different sexes. The male to female ratios were strikingly different between SIO (bays of the Novaya Zemlya Archipelago) and MMBI (west of the Yamal Peninsula) (Fig. 1): 0.8 and 3.8 respectively. There were only 8 ovigerous and 366 non ovigerous females in the SIO samples (ratio 0.02), while there were 72 ovigerous and only 67 non ovigerous females in the MMBI samples (ratio 1.07).

The central half of the CW size distribution of crabs differed between samples for all sexes, except for ovigerous females (Fig. 6). Ovigerous females were within a narrow size range of 44 and $58 \mathrm{~mm}$ in the SIO samples, and between 42 and 72 in the MMBI samples (Table 4). The non ovigerous females from SIO trawling samples ranged from 11 to $47 \mathrm{~mm}$. The MMBI non ovigerous females were larger and ranged from 22 to $63 \mathrm{~mm}$. Overall, male sizes also differed between these two sampling methods and area of collection. The CW of 293 crabs caught by SIO Sigsbee trawl ranged from 11 to $117 \mathrm{~mm}$, and of the 523 crabs caught by MMBI large trawl ranged from 23 to $120 \mathrm{~mm}$. Small mesh in the Sigsbee trawl allowed us to collect 190 juvenile crabs (less than $11 \mathrm{~mm}$ ).

\section{Abundance estimation}

Population density of crabs was calculated from the video transects (Table 5). Overall 3132 frames were analyzed, resulting in $3776 \mathrm{~m}^{2}$ of bottom inspected. The maximum density was observed near the Kara Gate Strait and in Blagopoluchiya Bay $\left(0.87\right.$ and $0.55 \mathrm{crabs} / \mathrm{m}^{2}$ 
287 respectively). In the other bays (located between the Kara Gate Strait and Blagopoluchiya Bay)

288 the population density of crabs was several times or an order of magnitude lower, reaching the 289 minimum value of $0.01 \mathrm{crabs} / \mathrm{m}^{2}$ in Haug Bay (Table 5).

290

291

292

293

294

295

296

297

298

299

300

301

302

303

304

305

306

307

308

309

310

311

312

313

314

315

316

\section{DISCUSSION}

\section{Advantages and disadvantages of the applied methods to study the snow crab}

\section{population in the Kara Sea}

The three methods discussed here revealed different aspects of the Chionoecetes opilio population size structure in the Kara Sea. The Sigsbee trawl used by SIO has small mesh and catches crabs as small as $4 \mathrm{~mm} \mathrm{CW}$, which is the size of recently settled crabs (Conan et al., 1996). However, it also has a small opening, and some large and agile crabs can escape. The video recording of the same area shows that large crabs are present, although not always caught. The large bottom trawl is able to catch large crabs $(22-120 \mathrm{~mm} \mathrm{CW})$, but does not retain younger crabs, due to its large mesh. We do however know that at least at some of the MMBI stations juvenile crabs were present. In some cases a similar to the SIO Sigsbee trawl was used, but the data was not dully recorded, and is thus omitted from the results. The combined use of this trawling gear could provide the full picture of the existing size groups in a population.

It is easy to observe larger crabs on the video, although some smaller crabs can also be spotted (up to $7 \mathrm{~mm} \mathrm{CW}$ ) (Fig $7 \mathrm{~A}$ ). The Video Module floats over the bottom with very little impact. Due to the muddy sediments in the studied area, every sudden movement of large agile organisms (crabs, fish) creates a cloud and can easily be spotted on the video. In all of the recorded footage, there were very few cases of such clouds: in most of them it was a fish, and sometimes crabs would run forward, and stop, therefore still recorded by us (Fig $7 \mathrm{C}$ ). It is safe to say that larger crabs (CW $30 \mathrm{~mm}$ and above) are quantitatively recorded on the video. However, crabs smaller than approximately $30 \mathrm{~mm}$ are probably substantially underestimated. Snow crabs are known to borrow in the sediments, especially in younger stages (Conan et al., 1996; Dionne et al., 2003). In some cases with good visibility, an outline of submerged crabs could be seen on the surface of the muddy sediments (Fig 7 B). Although, it is possible that a 
317 few crabs were not counted due to low visibility and deep burrowing. Therefore, the crab

318 densities calculated from the video footage can be largely underestimated.

319 The highest density of crabs recorded in 2016 was in Blagopoluchiya Bay (0.87

$320 \mathrm{crabs} / \mathrm{m}^{2}$ ). The crabs were small in both the Sigsbee trawl and on the video (majority of crabs

321 with $\mathrm{CW}$ below $20 \mathrm{~mm}$ ). Even though the mixture analysis identified two distinct small sized

322 groups (8-9 mm and 14-15 $\mathrm{mm}$ ) for both sampling methods, the trawling sample had much

323 sharper differences between the groups, and the larger groups were much more distinct (Fig. 3

324 A,B, Table 1). Such differences could be due to possible errors in size measurements of filmed

325 crabs. In the video samples, the $\mathrm{CW}$ was measured by a ruler, which has lower precision. In

326 addition, the measurements were recalculated based on the distance between the two laser points

327 that were also measured by a ruler. The crabs were not always in absolutely plain position

328 towards the camera, and the visibility often did not permit to see the edges of carapace clearly.

329 Therefore, there could be some additional noise in CW measurements from the video footage in

330 comparison to the direct measurements by calipers of live organisms.

331 However, the most important error in the identification of size groups using video

332 samples was due to sexual dimorphism. The size groups (instars) of Ch. opilio are extensively

333 described in the literature and the young crabs (pre puberty molting $<20-30 \mathrm{~mm}$ ) seem to have

334 similar size groups across their range of habitat (Ito, 1970; Ogata, 1973; Kon, 1980; Sainte-

335 Marie et al., 1995; Ernst et al., 2012). These instars are in accordance with those observed for

336 young crabs in the Kara Sea in 2014 (Zalota et al., 2018) and in 2016 (present study, Table 1).

337 After puberty molting (which was shown to be at 37-40 $\mathrm{mm}$ for males and $17 \mathrm{~mm}$ for females, in

338 the Gulf of St. Lawrence) crabs' growth rate and possible skipping of molts in females is

339 strongly affected by temperature (Sainte-Marie et al., 1995; Alunno-Bruscia \& Sainte-Marie,

340 1998; Dawe et al., 2012), which is less than 0 and $-1^{\circ} \mathrm{C}$ in most areas of the Kara shelf (Polukhin

341 \& Zagretdinova, 2016; see also Zalota et al., 2018). Further growth and survival success of

342 larger crabs may also be affected by low food availability for benthic predators in the Kara Sea

343 (Zenkevich, 1963; Kulakov et al., 2004). As they age further, they molt approximately once a

344 year, or even rarer until they reach their terminal molt (males at CW (postmoult) as small as 40

$345 \mathrm{~mm}$ up to $150 \mathrm{~mm}$; females 30-95 mm) (Ito, 1970; Robichaud et al., 1989; Comeau et al., 1998;

346 Sainte-Marie \& Hazel, 1992; Sainte-Marie et al., 1995; Alunno-Bruscia \& Sainte-Marie, 1998). 
Taking into account these errors, caused by aggregating males and females in video

348

349

350

351

352

353

354

355

356

357

358

359

360

361

362

363

364

365

366

367

368

369

370

371

372

373

374

375

376 samples, it is not surprising that crabs larger than $20 \mathrm{~mm}$ blur into one large size group in the video data, while crabs caught by the large MMBI trawl and measured more accurately can be separated into at least 4 size groups (Table 1, Fig. 2 B, C). Even finer size structure in the MMBI samples can be seen if crabs over $20 \mathrm{~mm}$ are separated according to sex (Table 1). Males have 7 distinct size groups over $20 \mathrm{~mm} \mathrm{CW}$, whereas, females' groups are more blurred. This can be due to the differences in molting and growth rates. Since video data cannot provide information on sexual dimorphism, the work done to study exact differences in the size structure of immature and mature crabs in the Kara Sea is not presented in this paper. Nevertheless, the obtained data still permits to identify general size groups and to approximate their relative quantities.

\section{Development of snow crabs' invasion and its possible role in Blagopoluchiya Bay}

Blagopoluchiya Bay appears to have very different size structure of the snow carb population compared to all other sampled areas. Most of the crabs, both caught in the trawl and in the video footage, were less than $20 \mathrm{~mm}$, and form 2 high frequency groups at around 10 and $15 \mathrm{~mm} \mathrm{CW}$ (Figs. $3 \mathrm{~A}, \mathrm{~B}, 4$; Table 1). These size groups correspond to the age of less than 2 years. In the Gulf of St. Lawrence it takes 16 to 17 months for crabs to achieve CW $10 \mathrm{~mm}$, and another 16 months to achieve size $20 \mathrm{~mm}$ through multiple molting events (Ogata, 1973; SainteMarie et al., 1995). Therefore, the majority of these crabs could not have settled much earlier than 2014. That year we caught crabs no bigger than $5 \mathrm{~mm}$ in the vicinity of that bay (station 51 in Zalota et al., 2018). Indeed, that was the first year when the crabs have been observed across the entire western Kara Sea and in most cases they were young, with high abundance of just settled crabs (Zalota et al., 2018).

There were a few larger crabs in Blagopoluchiya Bay that were caught on camera. Their sizes are not big enough to assume that they actively migrated from other areas. This suggests that there were earlier successful settlings of crabs, but the proportion of larger crabs is almost negligible (Fig. 3 A, B). The density of the young crabs in the bay is very high $(0.87$ crabs per $\mathrm{m}^{2}$ ) and in some cases we observed up to 8 crabs in one video frame (approximately $0.5 \mathrm{~m}^{2}$ ). Such high densities suggest that a recent combination of favorable oceanographic and sea ice 
377 conditions in this area facilitated a massive settling and survival of snow crabs. The larvae that

378 settled in Blagopoluchiya Bay were likely transported by the Eastern Novaya Zemlya current.

379 This current originates from the Barents Sea water, entering the Kara Sea off the northern

380 coast of the Novaya Zemlya and is directed to the south-west along the eastern coast of this

381 archipelago (Pavlov \& Pfirman, 1995). Previously, the bays of the Novaya Zemlya, especially in

382 the north, such as Blagopoluchiya Bay, have been blocked by ice longer than most of the western

383 Kara Sea (AARI, 2007-2014). Although, a narrow Northern Novaya Zemlya Polynya occurred

384 from time to time (Gavrilo \& Popov, 2011). Since 2011, changing sea conditions of the 2000 -

385 2010s manifested in an abrupt sea ice decrease in June (NOAA, Snow and Ice, 1979-2018).

386 Although, there was more ice in the spring of 2014 (in comparison to 2011), the sea ice cover

387 along the Novaya Zemlya Archipelago, was the first to retreat and an extensive polynya was

388 formed (AARI, 2007-2014). Early sea ice decay could have facilitated seasonal development of

389 phyto- and zooplankton, and hence favorable conditions for feeding and successful settling of

390 crab larvae.

391 When the first snow crabs were settling, they experienced small predator pressure in the

392 Kara Sea benthos. Adult snow crabs that are highly cannibalistic were not yet present, and the

393 native crab species, Hyas araneus, are very rare in that area (Anisimova et al., 2007; authors'

394 observations). In addition, predatory demersal fishes have substantially lower diversity and

395 abundance in the Kara than in the Barents Sea (Dolgov at al., 2009, 2014; Dolgov \& Benzik, 396 2016).

Initially snow crabs could have settled in the southern bays and in the central western part

398 of the Kara Sea (in addition to larvae transportation adults could have reached it by active

399 migration) before they reached the northern bays of the Novaya Zemlya Archipelago. Hence, we

400 can observe such difference in the population size structure of Blagopoluchiya Bay (narrow

401 range of size groups) in comparison to the southern areas (all size groups are present).

402

403

Indication of formation of spatial population structure

404

405

406

Overall, there seems to be a pattern in the snow crabs' size distribution across the western 407

Kara Sea. In the southern Kara Sea these patterns are not related to depth since there is no strong correlation between the $\mathrm{CW}$ and the depth across all MMBI stations (large bottom trawl). These 
408 stations are positioned on a broad, slightly sloping shallow shelf (46 to $195 \mathrm{~m}$ ). However there is 409 a visually observable trend of maximum sizes prevailing in the Kara Gates Strait and northwards 410 along the Yamal Peninsula (Fig. 5). This closely resembles prevailing current path of the Barents 411 Sea waters, known as the Yamal Current (Pavlov \& Pfirman, 1995; Zatsepin et al., 2010a). The 412 area along the Yamal Peninsula and the Novaya Zemlya Archipelago has higher benthic biomass 413 rates than in the center of the western Kara Sea (Antipova \& Semenov, 1989; Denisenko et al.,

414 2003; Kulakov et al., 2004; Kozlovskiy et al., 2011). The decrease of the maximum CW from the 415 Yamal Peninsula towards the center of the western Kara Sea could be due to lower food 416 availability further away from the Barents Sea influence, and thus the crabs have insufficient 417 nutrition to achieve larger sizes. However, this hypothesis needs further confirmation.

418 There could also be behavioral separation, where smaller sized crabs are forced to move 419 to a territory with less food to escape cannibalism, which is very common among this species 420 (Conan et al., 1996; Comeau et al., 1998). No such trends can be observed along the Novaya 421 Zemlya Archipelago, probably due to low sampling effort. There are reports of difference in the 422 habitat preferences of different sized snow crabs in their native habitat areas (Comeau et al., 423 1998; Ernst et al., 2012). The bays of the Novaya Zemlya have the potential to act as a nursery 424 for smaller, more vulnerable specimens, as it has been observed in the Gulf of St. Laurence 425 (Comeau et al., 1998). Whether this separation exists or will ever exist in the Kara Sea is hard to 426 say at this point. However, the vicinity of deep trough along the Novaya Zemlya Archipelago 427 could attract larger crabs and lead to size related migration out of the bays.

428 The recruitment of crabs at the early stages of population establishing in the Kara Sea 429 might be mostly due to the inflow of the larvae from the Barents Sea (Zalota et al., 2018). Here 430 we present findings of substantial number of ovigerous females, most of which have been found 431 along the Yamal Peninsula (with no apparent spatial or depth distribution patterns), and none in 432 the bays. It is hard to say whether this was due to sampling gear limitation to catch representative 433 sample of larger crabs or a reflection of the real picture. All ovigerous females had CW larger 434 than $40 \mathrm{~mm}$ (Fig. 6). This corresponds to the size of female's terminal (sexual maturity) molt 435 reported in the literature (starting from $35 \mathrm{~mm}$ ) (Sainte-Marie et al., 1995; Alunno-Bruscia \& 436 Sainte-Marie, 1998). Crabs of these sizes had a low catchment rate in the SIO trawling samples 437 along the Novaya Zemlya Archipelago. In most cases the video samples suggest that crabs with $438 \mathrm{CW}$ larger than $40 \mathrm{~mm}$ prevail in the vicinity of most sampled bays (Fig. 4). Therefore, it is 
439 likely that reproducing crabs are present in most sampled areas. It is safe to say, that at present 440 the snow crab opilio has a reproducing population in the Kara Sea.

441 The spatial structure of the snow crab population in the Kara Sea is still in process of 442 formation. The data of 2016 indicate that this process may lead to a quite complex system, which 443 is based on local recruitment, transport of larvae from the Barents Sea and across the western 444 Kara shelf, formation of nursery grounds, and an active migration of adults and their

445

446

447

448

449

450

451

452

453

454

455

456

457

458

459

460

461

462

463

464

465

466

467

468

469 concentration in particular shelf areas with appropriate feeding conditions. This system on the other hand can't be static as it is influenced by changing advection of the Barents Sea water and its interaction with the water of river discharge origin (Zatsepin et al., 2010b), sea ice regime, trophic conditions and predation pressure on juvenile crabs.

\section{CONCLUSION}

The present study compares and combines the results obtained using three different sampling gear to assess the size composition and density of the snow crab population. Smaller Sigsbee trawl allows catching of small crabs, even those that are just settled. A large commercial type trawl catches large agile crabs and results in a larger number of ovigerous females. Video transects probably underestimates smaller crabs, but gives a rapid and accurate estimate of larger crabs' densities. This method is helpful to monitor the spatial progress of the crabs' invasion and the appearance of commercial sized crabs. Trawling is necessary to study reproductive biology of crabs in new conditions and to carefully identify size structure of the population. The data of 2016 has finally proven that the Kara Sea snow crab opilio population is reproducing, although presumably still strongly influenced by the larval transport from the Barents Sea. We observed initial nursery areas in the bays of the eastern coast of the Novaya Zemlya Archipelago. A number of commercial sized crabs can be observed near the Kara Gate Strait and along the western coast of the Yamal Peninsula with higher food availability than the rest of the Kara Sea.

\section{ACKNOWLEDGEMENTS}

We would like to thank the Captains, the crews and the science teams and their leaders that participated during the RV Akademik Mstislav Keldysh SIO and RV Dalniye Zelentsy MMBI 
470 cruises to the Kara Sea in 2016. We are particularly grateful to the team of engineering and 471 technical research of SIO for creating and using an uninhabited, towed, submerged, inert vehicle 472 (UTSI) Video Module to film the footage during the SIO expedition.

473

474

475

476

477

478

479

480

481

482

483

484

485

486

487

488

489

490

491

492

493

494

495

496

497

498

499

500

\section{REFERENCES}

AARI, 2007-2014, General maps of sea ice cover. St. Petersburg: Arctic and Antarctic Research Institute (AARI), http://www.aari.ru/odata/_d0004.php?m=Kar\&lang=0\&mod=0\&yy=2014 (Accessed 25.11.2018).

AARI, 2009, Winter Kara Sea Atlas, http://www.aari.ru/resources/a0013_17/kara/Atlas_Kara_Sea_Winter/text/rejim.htm (Accessed 25.11.2018).

Akaike H. 1974. A new look at the statistical model identification. IEEE Transactions on Automatic Control 19:716-723.

Alunno-Bruscia, M., Sainte-Marie, B. 1998. Abdomen allometry, ovary development, and growth of female snow crab, Chionoecetes opilio (Brachyura, Majidae), in the northwestern Gulf of St. Lawrence. Canadian Journal of Fisheries and Aquatic Sciences. 55(2): 459-477.

Alvsvåg, J., Agnalt, A. \& Jørstad, K. 2009. Evidence for a permanent establishment of the snow crab (Chionoecetes opilio) in the Barents Sea. Biological Invasions, 11: 587-595.

AMAP Assessment. 2015. Temporal Trends in Persistent Organic Pollutants in the Arctic. Arctic Monitoring and Assessment Programme (AMAP), Oslo, Norway. vi+71pp

Amiragyan, A. 2017. Development of oil and gas resources of the Russian Arctic shelf: problems and prospects. Business journal Neftegaz Ru. 8:16-22. (In Russian)

Anisimova, N.A., Ljubin, P.A., Menis, D.T. 2007. Benthos. In: PrischepaB.F. (ed) Ecosystem of the Kara Sea. PINRO publishing, Murmansk: 43-105 (in Russian).

Antipova, T.V., Semenov, V.N. 1989. Composition and distribution of benthos in the southwestern regions of typical sea waters of the Kara Sea. Ecology and Bioresources of the Kara Sea. Apatity: Publishing house KSC RAS: 127-137. (In Russian).

Ashik, I.M., Karklin, V.P., Kirillov, S.A., Radionov, V.F., Timokhov, L.A. 2014. Impact of climate change on marine natural systems. Arctic Seas of Russia. In The second 
501

502

503

504

505

506

507

508

509

510

511

512

513

514

515

516

517

518

519

520

521

522

523

524

525

526

527

528

529

530

assessment report on climatic changes and their consequences in the territory of Russian Federation. Moscow, State Hydrometeorological Service: 578-615. http://voeikovmgo.ru/index.php?option=com_content\&view=article\&id=649\&Itemid=24 \&lang=ru (Access 01.12.2018) (In Russian).

Byers, J.E., Smith R.S., Pringle, J.M., Clark, G.F., Gribben, P.E., Hewitt, C.L., Inglis, G.J., Johnston, E.L., Ruiz, G.M., Stachowicz, J., Bishop, M.J. 2015. Invasion Expansion: Time since Introduction Best Predicts Global Ranges of Marine Invaders. Scientific Reports, 5: 12436. https://doi.org/10.1038/srep12436

Bakanev, S.V. 2015. Dispersion and assessment of possible distribution of snow crab opilio (Chionoecetes opilio) in the Barents Sea. Principles of Ecology, 3:27-29. (In Russian)

Bakanev, SV, Dvoretsky, A., Pavlov, V.A., Pinchukov, M., Zacharov, D., Zolotarev, P. 2016 Commercial shellfsh: status of commercial stocks. In: Joint Norwegian-Russian environmental status 2013. Report on the Barents Sea Ecosystem. Part II-Complete report. Ed. by M.M. McBride, J.R. Hansen, O. Korneev, O. Titov. Co-ed. by J.E. Stiansen, J. Tchernova, A. Filin, A. Ovsyannikov. IMR/PINRO Joint Report Series, $1: 224-241$.

Bakanev, S.V., Pavlov, V.A., Goryanina, S.V. 2017. Material justifying correction of the total allowable catch of the snow crab in the EEZ of Russia in the Barents Sea in 2017. NM Knipovich Polar Institute of Fishery and Oceanography, Murmansk www.pinro.ru/15/images/stories/news/cor-odu-opilio2017.docx. (Access 20.05.2017) (In Russian)

Comeau, M., Conan, G., Maynou, F., Robichaud, G., Therriault, J., Starr, M. 1998. Growth, spatial distribution, and abundance of benthic stages of the snow crab (Chionoecetes opilio) in Bonne Bay, Newfoundland, Canada. Canadian Journal of Fisheries and Aquatic Sciences, 55:262-279.

Conan, G., Starr, M., Comeau, M., Therriault, J., Robichand, G., Hernàndez, F. 1996. Life history strategies, recruitment fluctuations, and management of the Bonne Bay Fjord Atlantic snow crab (Chionoecetes opilio). Proceedings of the international symposium on biology, management, and economics of crabs from high latitude habitats. University of Alaska Sea Grant College Program Report: 96-102. 
531 Chava, A.I., Udalov, A.A., Vedenin, A.A., Simakov, M.I., Shchuka, S.A., Mokievsky, V.O.

532

533

534

535

536

537

538

539

540

541

542

543

544

545

546

547

548

549

550

551

552

553

554

555

556

557

558

559

560 2017, Benthic Fauna of Tsivolki Bay (Novaya Zemlya Archipelago, Kara Sea). Oceanology. 57(1):160-170.

Chuchukalo, V.I., Nadtochiy, V.A., Fedotov, P.A., Bezrukov, R.G. 2011. Feeding habits and some aspects of biology of snow crab opilio (Chionoecetes opilio) in Chukchi Sea. Izv. TINRO, 167:197-206.

Dawe E.G., Mullowney D.R., Moriyasu M., Wade E., 2012, Effects of temperature on size-atterminal molt and molting frequency in snow crab Chionoecetes opilio from two Canadian Atlantic ecosystems, Marine Ecology Progress Series Mar Ecol Prog Ser Vol. 469: 279-296, 2012

Demidov, A.B., Mosharov. S.A. 2015. Vertical distribution of primary production and chlorophyll a in the Kara Sea. Oceanology. 55:521-534.

Demidov, A.B., Mosharov, S.A., Makkaveev, P.N. 2015. Evaluation of environmental factors infuence on Kara Sea primary production in autumn. Oceanology 55:535-546.

Denisenko, N.V., Rachor, E., Denisenko, S.G. 2003. Benthic fauna of the southern Kara Sea. In Siberian river run off in the Kara Sea. Ed. by Stein R., Fahl K., Fütterer D.K., Galimov E.M., Stepanets O.V. Elsevier Science: 2013-236.

Dionne, M., B. Sainte-Marie, E. Bourget, and D. Gilbert. 2003. Distribution and habitat selection of early benthic stages of snow crab, Chionoecetes opilio. Marine Ecology Progress Series, 259:117-128

Dolgov, A.V., Benzik, A.N. 2016. Snow crab opilio as a prey for fish in the Barents Sea. In Snow crab Chionoecetes opilio in the Barents and Kara Seas. Ed. by Sokolov K.M., Strelkova, N.A., Manushin, I.E. and Sennikov A.V. PINRO Publishing, Murmansk: 140155. (In Russian)

Dolgov, A.V., Benzik, A.N., Chetyrkina, O.Yu. 2014. Feeding peculiarities of non-target fish and their role in productivity of the Kara Sea ecosystem. Trudy VNIRO, 152:190-208. (In Russian)

Dolgov, A.V., Smirnov, O., Drevetnyak, K.V., Chetyrkina, O.Yu. 2009. New data on composition and structure of the Kara Sea ichthyofauna. ICES CM 2009/E:32.Ernst, B., Armstrong. D.A., Burgos, J., Orensanz, J.M. 2012. Life history schedule and periodic 
561

562

563

564

565

566

567

568

569

570

571

572

573

574

575

576

577

578

579

580

581

582

583

584

585

586

587

588

589

590

591

recruitment of female snow crab (Chionoecetes opilio) in the eastern Bering Sea. Canadian Journal of Fisheries and Aquatic Sciences 69:532-550.

Ernst B, Armstrong DA, Burgos J, Orensanz JM, 2012, Life history schedule and periodic recruitment of female snow crab (Chionoecetes opilio) in the eastern Bering Sea. Can J Fish Aquat Sci 69:532-550

Gavrilo, V.V., Popov, A.V. 2011. Sea ice biotopes and biodiversity hotspots of the Kara and the north-eastern Barents Sea. In Atlas of the Marine and Coastal Biodiversity of the Russian Arctic. Ed. by V.A, Gavrilo, M.V., Nikolaeva, N.G., Krasnova. Moscow, WWF Russia: $34-35$.

Grobe, H., Diepenbroek, M., Siems, U. 2003. PanMap - a Mini-GIS (Geographical Information System) to draw point and vector data in maps including geographical resources. Alfred Wegener Institute, Helmholtz Centre for Polar and Marine Research, Bremerhaven, PANGAEA, https://doi.org/10.1594/PANGAEA.104840

Hammer, Ø. 2013. PAST: Paleontological Studies Version 3.0: Reference Manuel. Natural History Museum. Olso. http://folk.uio.no/ohammer/past/past3manual.pdf (Accessed 03.10.2016).

Hammer, M. and Hoel, A.H. 2012. The Development of Scientific Cooperation under the Norway-Russia Fisheries Regime in the Barents Sea. Arctic Review on Law and Politics, 3(2):244-274. ISSN 1891-625

Ho, J. 2010. The implications of Arctic sea ice decline on shipping. Marine Policy, 34(3):713715.

Ito, K. 1970. Ecological studies on the edible crab. Chionoecetes opilio (O. Fabricius) in the Japan Sea. II. Age and growth as estimated on the basis of the seasonal changes in the carapace width frequencies and the carapace hardness. Bull. Jpn. Sea Reg. Fish. Res. Lab., 22: 81-116.

Jørgensen, L.L., Pearson, T.H., Anisimova, N.A., Gulliksen, B., Dahle, S., Denisenko, S.G., Matishov, G.G. 1999. Environmental influences on benthic fauna associations of the Kara Sea (Arctic Russia). Polar Biol. 22: 395-416.

Jørgensen, L.L., Lyubin, P.A., Skjoldal, H.R., Ingvaldsen, R.B., Anisimova, N.A., Manushin, I.E. 2015. Distribution of benthic megafauna in the Barents Sea: Baseline for an ecosystem approach to management. ICES Journal of Marine Science, 72:595-613. 
592 Kolts, J.M., Lovvorn, J.R., North, C.A., Grebmeier, J.M., Cooper L.W. 2013. Effects of body

593

594

595

596

597

598

599

600

601

602

603

604

605

606

607

608

609

610

611

612

613

614

615

616

617

618

619

620

size, gender, and prey availability on diets of snow crabs in the northern Bering Sea. Marine Ecology Progress Sereis, 483:209-220.

Kon, T. 1980. Studies on the life history of the zuwai crab, Chionoecetes opilio (O. Fabricius). Spec. Publ. Sado Mar. Biol. Stn., Niigata Univ. 2:64 pp.

Kozlovskiy, V.V., Chikina, M.V., Kucheruk, N.V., Basin, A.B. 2011. Structure of the macrozoobenthic communities in the Southwestern Kara Sea. Oceanology, 51(6):10121020.

Kulakov, M.Yu., Pogrebov, V.B., Timofeyev, S.F., Chernova, N.V., Kiyko, O.A. 2004. Chapter 29. Ecosystem of the Barents and Kara Seas, coastal segment (22,P). In The Sea, Volume 14. Ed. by A.R. Robinson and K.H. Brink ISBN 0-674- C2004 by the President and Fellows of Harvard College. pp 1135-1172.

Kuzmin, S.A., Akhtarin, S.M., Menis, D.T. 1998. The first finding of snow crab Chionoecetes opilio (Decapoda, Majidae) in the Barents Sea. Zoologicheskiy Zhurnal. 77:489 - 491. (In Russian)

Liua, M., Kronbak, J. 2010. The potential economic viability of using the Northern Sea Route (NSR) as an alternative route between Asia and Europe. Journal of Transport Geography Volume 18(3):434-444.

Lovvorn, J. 2010. Predicting snow crab growth and size with climate warming in the northern Bering Sea. North Pacific Research Board, Final Report, 713. 24 pp.

NOAA, Snow and Ice, Regional Sea Ice, 1979-2018, https://www.ncdc.noaa.gov/snow-andice/regional-sea-ice/extent/Kara/6 (Accessed 25.11.2018).

Ogata, T. 1973. Studies on the population biology of the edible crab, Chionoecetes opilio O. Fabricius in the Japan Sea Region. Mar. Sci. Men., 5(3):27-33.

Pavlov, V. A. 2006. New data on snow crab (Chionoecetes opilio (Fabricius, 1798)) in the Barents Sea. In VII All-Russian Conference on Commercial Invertebrates, Murmansk, 913 October 2006. Moscow, VNIRO Publishing: 109-111. (In Russian)

Pavlov, V.K., Pfirman, S.L. 1995. Hydrographic structure and variability of the Kara Sea: implications for pollutant distribution. Deep Sea Res II 42:1369-1390. 
621 Pavlov, V.A., Sundet, J.H. 2011. Snow crab. In The Barents Sea ecosystem, resources,

622

623

624

625

626

627

628

629

630

631

632

633

634

635

636

637

638

639

640

641

642

643

644

645

646

647

648

649

650

651 management. Half a century of Russian-Norwegian cooperation. Trondheim, Tapir Academic Publishing: 168-172.

Polukhin, A.A., Zagretdinova, D.R. 2016. Oceanographical characteristics of the Kara Sea. In Russian Arctic Sea Atlases. Ecological Atlas. Kara Sea. Ed. by Isachenko, A.I. Moscow, Arctic Science Center: 53-76. (In Russian)

Pronin, A.A. 2017. Methodology of collecting and presenting material of video footage of bottom with the help if uninhabited, submerged vehicle "Video module". International journal of applied and fundamental research, 12(1):142-147. (In Russian)

R Core Team. 2018. R: A language and environment for statistical computing. R Foundation for Statistical Computing, Vienna, Austria. URL https://www.R-project.org/.

Robichaud, D. A., Bailey, R. F. J., Elner, R. W. 1989. Growth and distribution of snow crab, Chionecetes opilio, in the southeastern Gulf of St. Lawrence. J. Shellf. Res., 8:13-23.

Romankevich, E.A., Vetrov, A.A. 2001. Carbon Cycle in the Arctic Seas of Russia. Nauka, Moscow. (In Russian)

RStudio Team. 2016. RStudio: Integrated Development for R. RStudio, Inc., Boston, MA URL http://www.rstudio.com/.

Sainte-Marie B, Hazel F, 1992, Moulting and mating of snow crabs (Chionoecetes opilio O. Fabricius), in shallow waters of the northwestern Gulf of Saint Lawrence. Can J Fish Aquat Sci 49:1282-1293

Sainte-Marie, B., Raymond, S., Brêthes, J.-C. 1995. Growth and maturation of the benthic stages of male snow crab, Chionoecetes opilio (Brachyura: Majidae). Canadian Journal of Fisheries and Aquatic Sciences, 52(5):903-924.

Sirenko, B.I. and Vassilenko, S.V. 2008. Crabs (Crustacea, Decapoda, Brachyura) of the Chukchi Sea. In Fauna and zoogeography of the Chukchi Sea. Explorations of fauna of the sea, Volume 61. Ed. by Sirenko B.I. St. Petersburg: Zoological Institute of Russian Academy of Sciences, 142-148 pp. (In Russian)

Slizkin, A.G. 1982. Distribution of snow crabs of the genus Chionoecetes and their habitat in the northern part of the Pacific Ocean. Izvestia TINRO. 106:26-33. (In Russian)

Slizkin, A.G., Fedotov, P.A., Khen, G.V. 2007. Spatial structure of settlements and some aspects of the biology of snow crab opilio in the Russian sector of the Chukchi Sea. Marine

Peer) reviewing PDF | (2019:04:36317:2:0:NEW 21 Sep 2019) 
652

653

654

655

656

657

658

659

660

661

662

663

664

665

666

667

668

669

670

671

672

673

674

675

676

677

678

679

680

commercial invertebrates and seaweeds. Biology and fishery. In honor of $70^{\text {th }}$ birthday anniversary of B.G. Ivanov. Moscow, VNIRO: 144 - 157.

Sokolov VI, Petryashov VV, Vassilenko SV, 2009 Order Decapoda. In: Vasilenko SV (eds) Illustrated keys to free living invertebrates of Eurasian Arctic Seas and adjacent deep waters, Vol. 1. Rotifera, Pycnogonida, Cirripedia, Leptostraca, Mysidacea, Hyperiidea, Caprellidea, Euphausiacea, Dendrobranchiata, Pleocyemata, Anomura, and Brachyura. Alaska Sea Grant, University of Alaska Fairbanks, pp 12-178.

Sokolov, K.M., Strelkova, N.A., Manushin, I.E., Sennikov, A.V. (eds). 2016. Snow crab Chionoecetes opilio in the Barents and Kara Seas. PINRO, Murmansk ISBN 978-586349-221-6. (In Russian).

Spiridonov, V.A. and Zalota, A.K. 2017. Understanding and forecasting dispersal of non-indigenous marine decapods in East European and North Asian waters. Journal of the Marine Biological Association of the UK, 97:591-611.

Squires, H.J. 1990. Decapod crustacea of the Atlantic coast of Canada. Canadian Bulletin of Fishery and Aquatic Science, 221:1-532.

Strelkova, N.A. 2016. On acclimatization of snow crab opilio in the Barents and the Kara Seas. In Snow crab Chionoecetes opilio in the Barents and Kara Seas. pp. 17-34. Ed. by K.M. Sokolov, N.A. Strelkova, I.E. Manushin, A.V. Sennikov. PINRO, Murmansk. (In Russian)

Sundet, J.H., and Bakanev, S. 2014. Snow crab (Chionoecetes opilio) - A new invasive crab species becoming an important player in the Barents Sea ecosystem. ICES CM 2014/F:04.

Tarverdieva, M.I. 1981. On the feeding habits of snow crabs Chionoecetes opilio and Ch. bairdi in the Bering Sea. Zoological journal, 60(7):287-293.

Udalov, A.A., Vedenin, A.A., Simakov, M.I. 2016. Benthic Fauna of Blagopoluchiya Bay (Novaya Zemlya Archipelago, Kara Sea). Oceanology, 56(5): 720-730.

Vinogradov, M.E., Vedernikov, V.I., Romankevich, E.A., Vetrov, A.A. 2000. Components of the carbon cycle in the Russian Arctic seas: primary production and flux of Corg from the photic layer. Oceanology, 40:204-215. 
681 Zakharov, D.V., Manushin, I.E., Strelkova, N.A., Pavlov, V.A., Nosova T.B., 2018. Diet of the 682 snow crab in the Barents Sea and macrozoobenthic communities in the area of its 683 distribution. Trudy VNIRO, 172:70-90.

684 Zalota, A.K., 2017. Non indigenous species of Crustacea Decapoda in Russian seas and 685 contiguous waters. PhD dissertation. Moscow. 234 pp. (In Russian)

686 Zalota, A.K., Spiridonov, V.A., Vedenin, A.A. 2018 Development of snow crab Chionoecetes 687 opilio (Crustacea: Decapoda: Oregonidae) invasion in the Kara Sea. Polar Biology, 688 41(10):1983-1994. DOI:10.1007/s00300-018-2337-y

689 Zatsepin, A.V., Morozov, E.V., Paka, V.T., Demidov, A,N, Kondrashov, A.A., Korzh, A.O., 690 Krementskiy, V.V., Poyarkov, S.G., Soloviev, D.M. 2010a. Circulation in the 691 southwestern part of the Kara Sea in September 2007. Oceanology, 50: 643-656.

692 Zatsepin, A.G., Zavialov, P.O., Kremenetskiy, V.V., Poyarkov, S.G., Soloviev, D.M. 2010b. The 693 upper desalinated layer water propagation and transformation in the Kara Sea. 694 Oceanology, 50: 657-667.

695 Zatsepin, A.G., Poyarkov, S.G., Kremenetskiy, V.V., Nedospasov, A.A., Shchuka. S.A., 696 Baranov, V.I., Kondrashov, A.A., Korzh, A.O. 2015. Hydrophisical features of deep 697 water troughs in the Kara Sea. Oceanology, 55: 472-484.

698 Zenkevich, L.A. 1963. Biology of USSR seas. Moscow, press ASci USSR. 740 pp.

699 Zimina, O.L. 2014. Finding the snow crab Chionoecetes opilio (O. Fabricius, 1788) (Decapoda:

700 Majidae) in the Kara Sea. Russian Journal of Marine Biology, 40:490-492.

701 Zimina, O.L., Lyubin, P.A., Jørgensen, L.L., Zakharov, D.V., Lyubina, O.S. 2015. Decapod

702 crustaceans of the Barents Sea and adjacent waters: species composition and peculiarities 703 of distribution. Arthropoda Selecta, 24:417-428. 


\section{Table $\mathbf{1}$ (on next page)}

Results of mixing model analysis of all Chionoecetes opilio carapace width (CW) measured from trawling ( $\mathrm{MMBI}$ and $\mathrm{SIO}$ ) collections and video footage from the Kara Sea in 2016. 


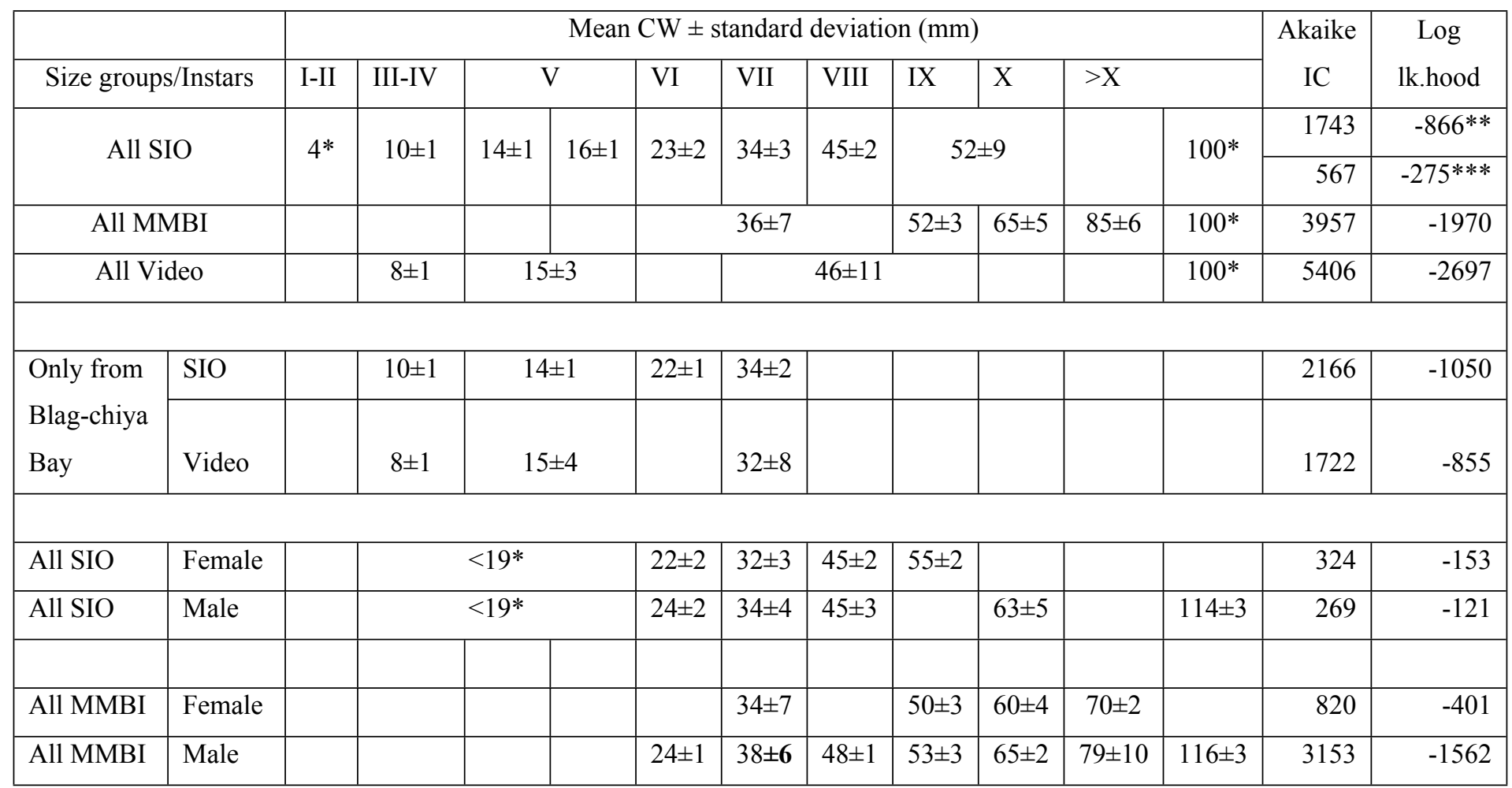




\section{Table 2 (on next page)}

General statistics of the carapace width (CW) distribution of crabs caught at SIO trawling $(A)$ and video sampling $(B)$ stations.

n- number of crabs measured; min-mas - minimum and maximum CW, central $50 \%$ - reflect the data between first and third quartile (50\%) of CW distribution (see Fig. 4). 


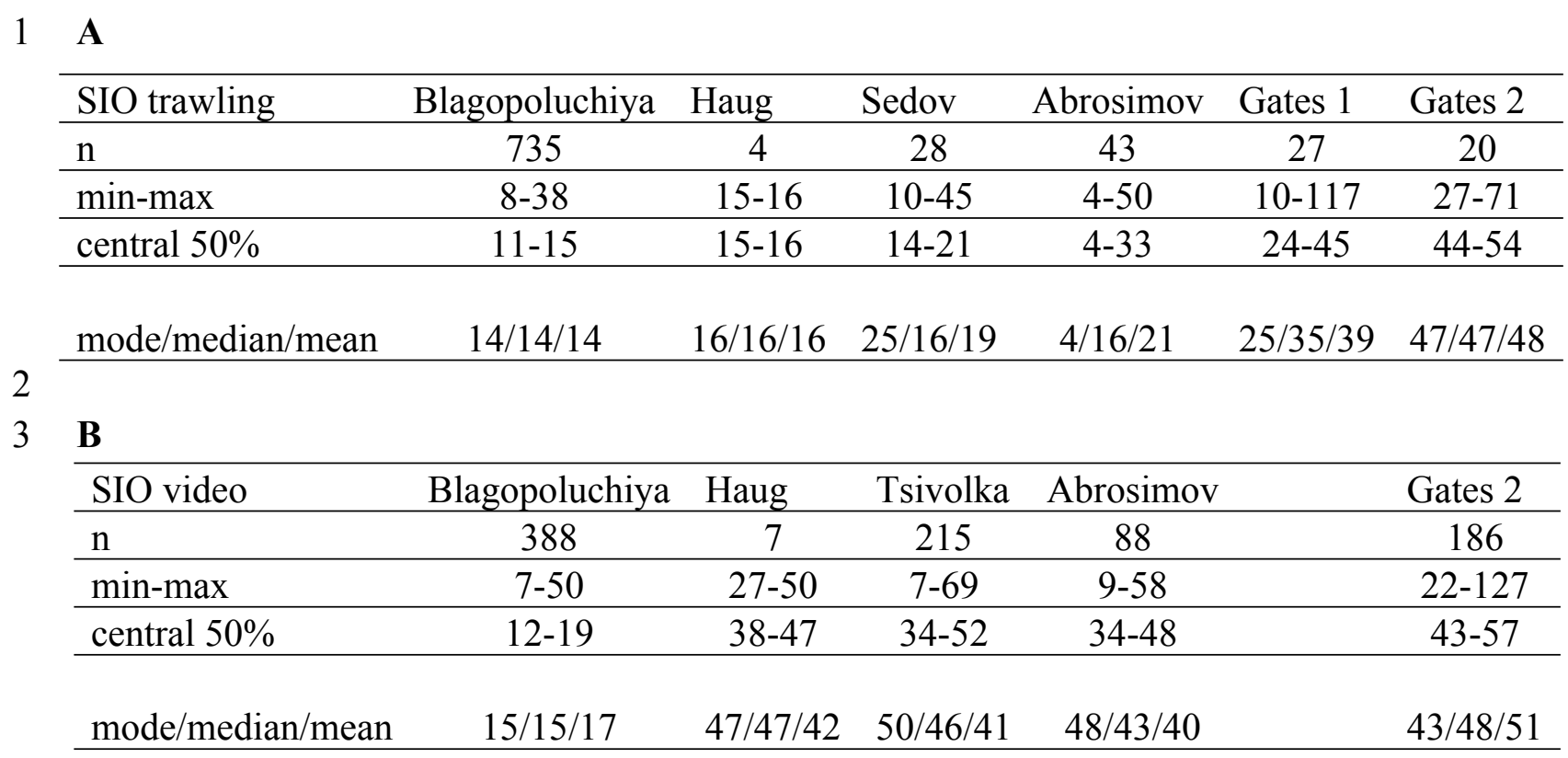

4 


\section{Table 3(on next page)}

Correlation of carapace width parameters with the sample stations' depth of SIO RAS trawling (6 stations) and video (5 stations), and MMBI (53) stations. 


\begin{tabular}{cccccc}
\hline & & Minimum & Maximum & Mode & Mean \\
\hline \multirow{2}{*}{ MMBI } & $\mathrm{p}$ & 0.004 & 0.48 & 0.54 & 0.37 \\
\cline { 2 - 6 } & $\mathrm{R}^{2}$ & $2.0 \mathrm{E}^{-05}$ & 0.24 & 0.29 & 0.14 \\
\hline \multirow{2}{*}{$\mathrm{IO}$} & $\mathrm{p}$ & 0.36 & 0.93 & 0.56 & 0.86 \\
\cline { 2 - 6 } & $\mathrm{R}^{2}$ & 0.13 & 0.87 & 0.31 & 0.73 \\
\hline \multirow{2}{*}{ Video } & $\mathrm{p}$ & 0.53 & 0.91 & 0.07 & 0.53 \\
\cline { 2 - 6 } & $\mathrm{R}^{2}$ & 0.28 & 0.83 & 0.004 & 0.28 \\
\hline
\end{tabular}

1 


\section{Table 4 (on next page)}

General statistics of the carapace width (CW) distribution of crabs of different sexes caught in SIO and MMBI trawling samples.

n- number of crabs measured; min-mas - minimum and maximum CW, central $50 \%$ - reflect the data between first and third quartile (50\%) of CW distribution (see Fig. 6). 
$1 \mathbf{A}$

\begin{tabular}{lcccc}
\hline IO trawling & Males & Females & $\begin{array}{c}\text { Ovigerous } \\
\text { females }\end{array}$ & Juveniles \\
\hline $\mathrm{n}$ & 293 & 366 & 8 & 190 \\
\hline min-max & $11-117$ & $11-47$ & $44-58$ & $4-11$ \\
\hline central 50\% & $14-16$ & $14-16$ & $49-56$ & $9-10$ \\
\hline & & & & \\
mode/median/mean & $14 / 15 / 18$ & $14 / 15 / 17$ & $55 / 54 / 52$ & $10 / 10 / 9$ \\
\hline
\end{tabular}

2

3 B

\begin{tabular}{lccc}
\hline MMBI trawling & Males & Females & $\begin{array}{c}\text { Ovigerous } \\
\text { females }\end{array}$ \\
\hline $\mathrm{n}$ & 523 & 67 & 72 \\
\hline min-max & $23-120$ & $22-63$ & $42-72$ \\
\hline central $50 \%$ & $51-66$ & $33-51$ & $58-66$ \\
\hline
\end{tabular}

$\begin{array}{llll}\text { mode/median/mean } & 52 / 55 / 58 & 48 / 45 / 42 & 62 / 61 / 61\end{array}$

4 


\section{Table 5 (on next page)}

The results of the analysis of video data of Chionoecetes opilio filmed by SIO RAS in the Kara Sea in 2016. 


\begin{tabular}{lcccc}
\hline & $\begin{array}{c}\text { Number of } \\
\text { video frames }\end{array}$ & $\begin{array}{c}\text { Total video } \\
\text { area } \mathrm{m}^{2}\end{array}$ & $\begin{array}{c}\text { Number } \\
\text { crabs }\end{array}$ & $\begin{array}{c}\text { Density } \\
\text { crabs } / \mathrm{m}^{2}\end{array}$ \\
\hline $\begin{array}{l}\text { Blagopoluchiya } \\
\text { Bay }\end{array}$ & 405 & 449 & 389 & 0.87 \\
\hline Haug Bay & 578 & 629 & 7 & 0.01 \\
\hline Tsivolka Bay & 1077 & 1355 & 204 & 0.15 \\
\hline Abrosimov Bay & 629 & 1130 & 86 & 0.08 \\
\hline Kara Gates 2 & 443 & 213 & 118 & 0.55 \\
\hline
\end{tabular}

1 
Figure 1

Map of stations surveyed by the RV Dalniye Zelentsy (MMBI) and the RV Akademik Mstislav Keldysh (SIO RAS) in August-September 2016 in the Kara Sea.

CIRCLES - MMBI bottom trawling stations; DIAMONDS - SIO RAS Sigsbee trawling stations; and STARS - stations with video footage of the bottom using UTSI Video module. (Maps created using PanMap; Grobe et al., 2003) 


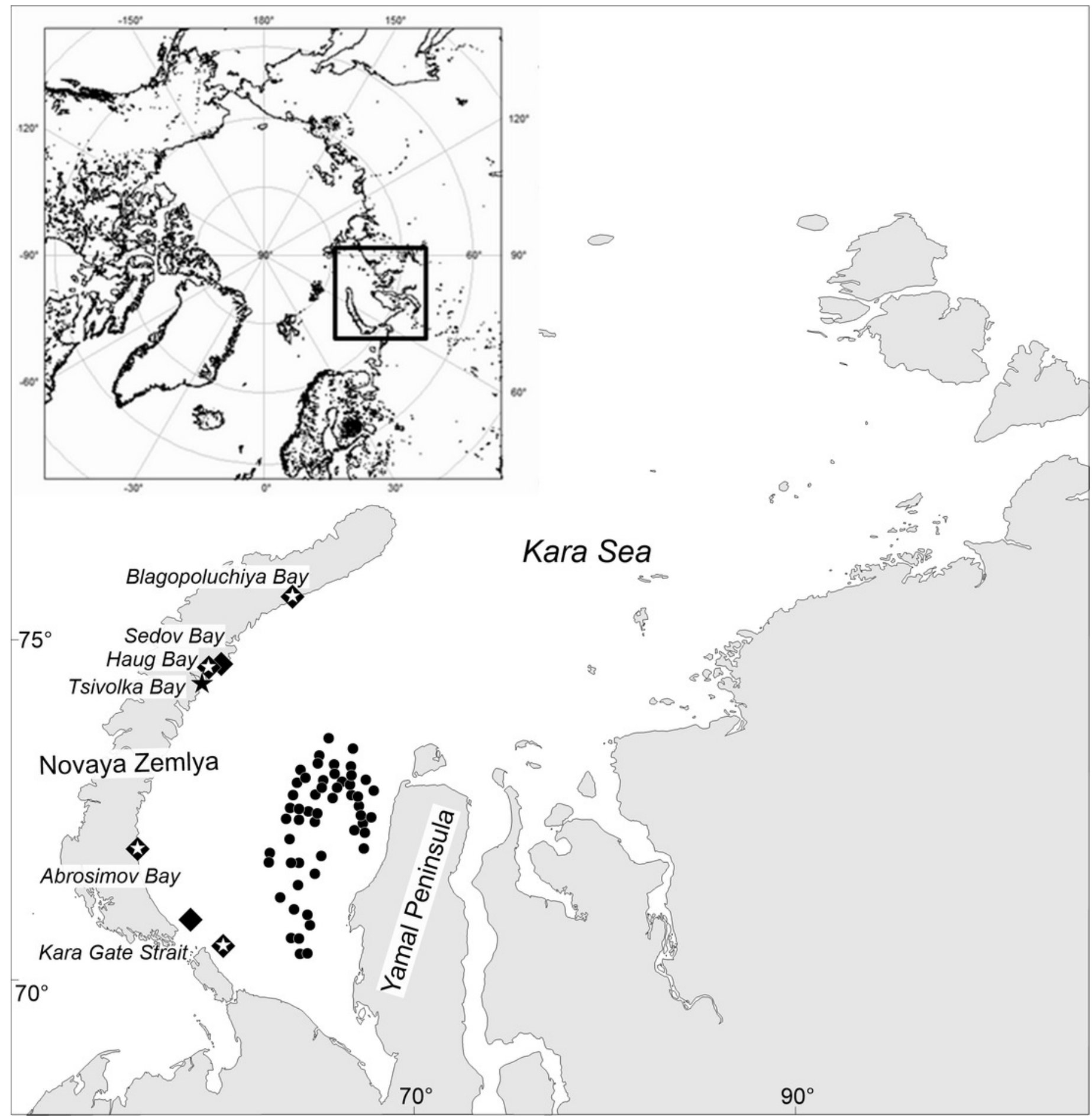


Figure 2

Carapace width (CW) size group frequencies of Chionoecetes opilio collected and measured by different methods from the Kara Sea, 2016.

A. All SIO samples collected by Sigsbee trawl; B. MMBI samples collected by a large bottom trawl; C. All data obtained from video footage. 

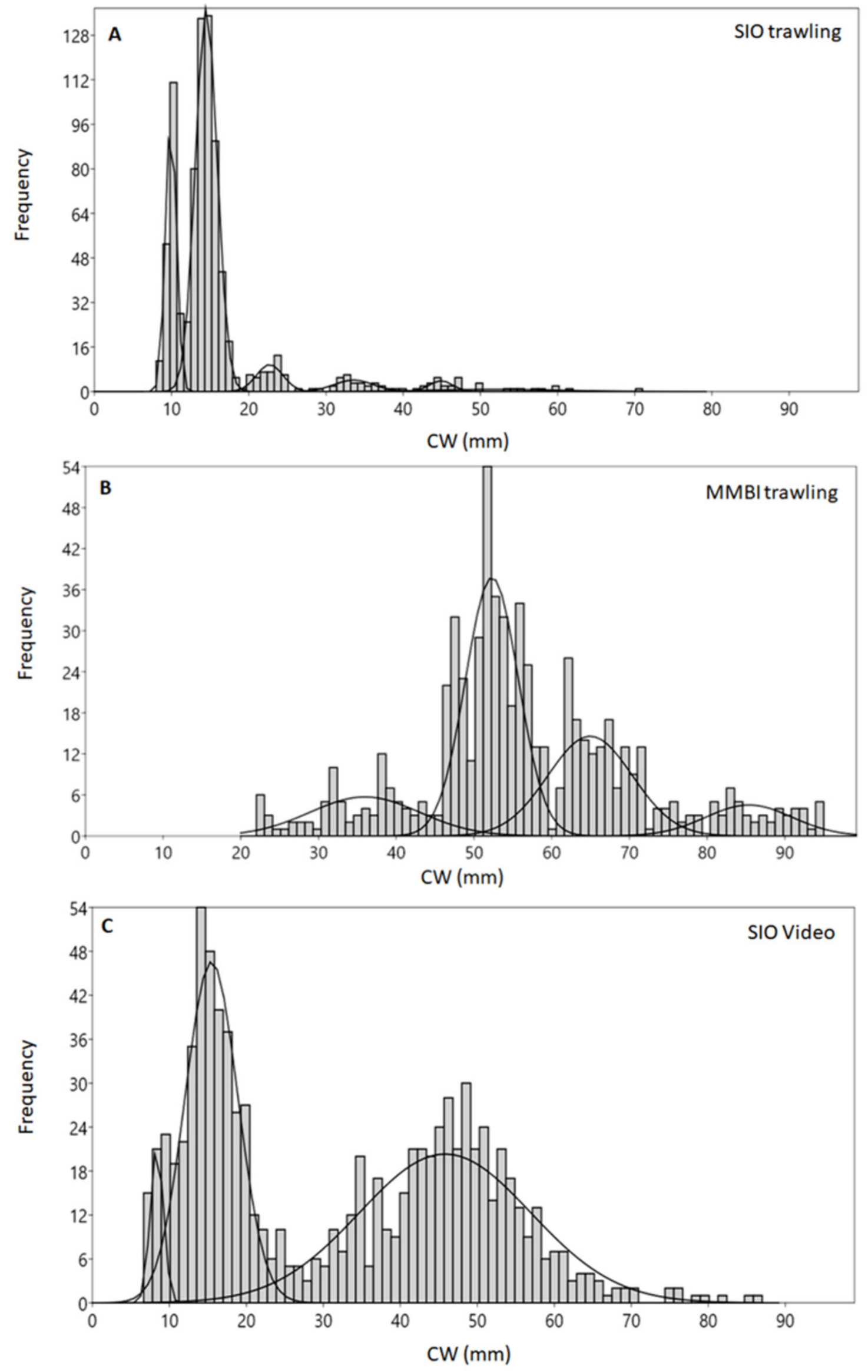

Peer) reviewing PDF | (2019:04:36317:2:0:NEW 21 Sep 2019) 
Figure 3

Carapace width (CW) size group frequencies of Chionoecetes opilio collected and measured by different methods from the vicinity of Blagopoluchiya Bay in 2016.
A. Video data collected prior to trawling; B. SIO Sigsbee trawling. 

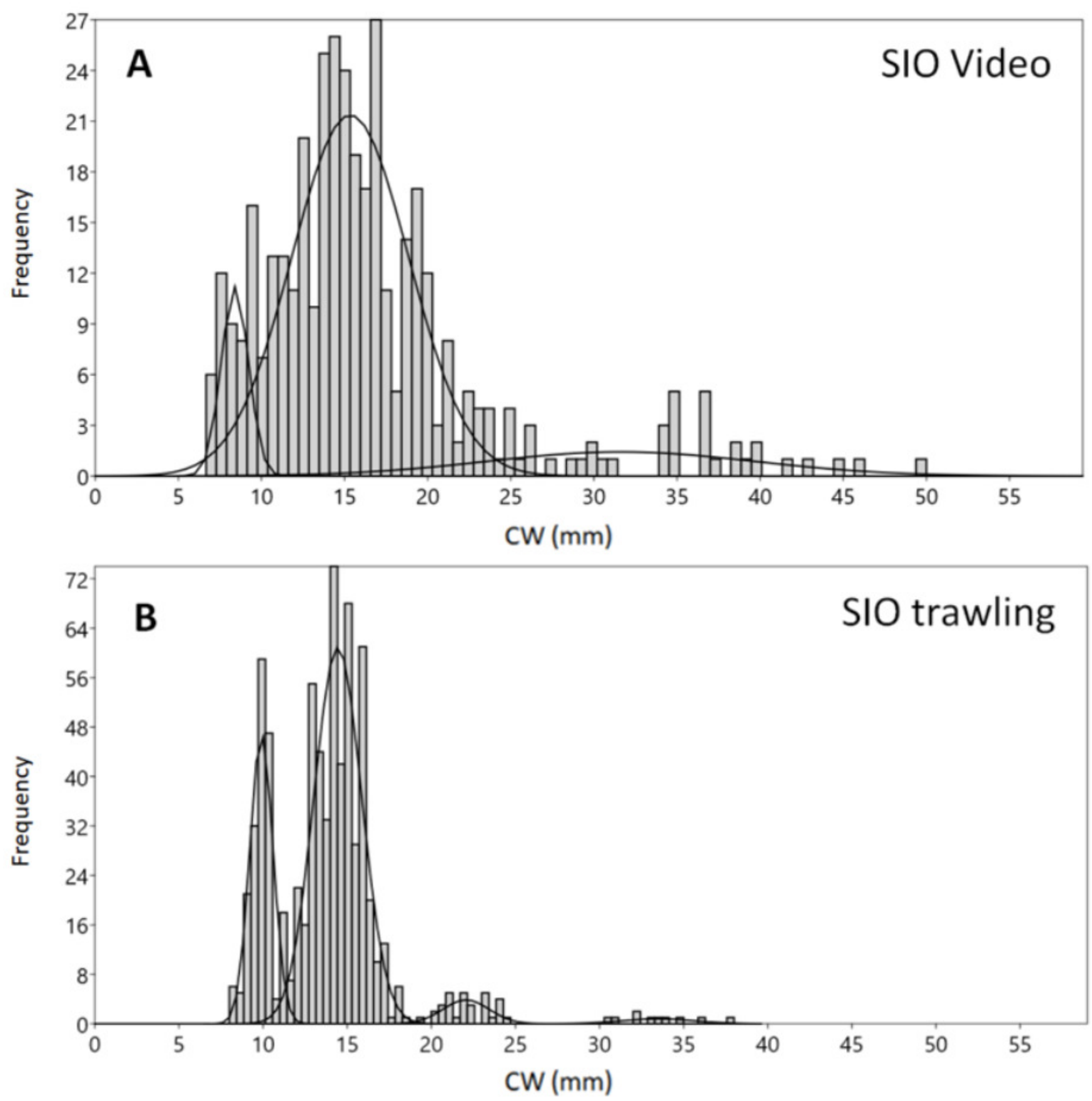
Figure 4

Box plots of carapace width (CW) distribution of crabs caught at SIO RAS stations.

A. Trawling stations; B. Video sampling stations. Boxes reflect data between first and third quartile (50\%), thick line is the median, and whiskers extend to the maximum and minimum CWs (see Table 2).
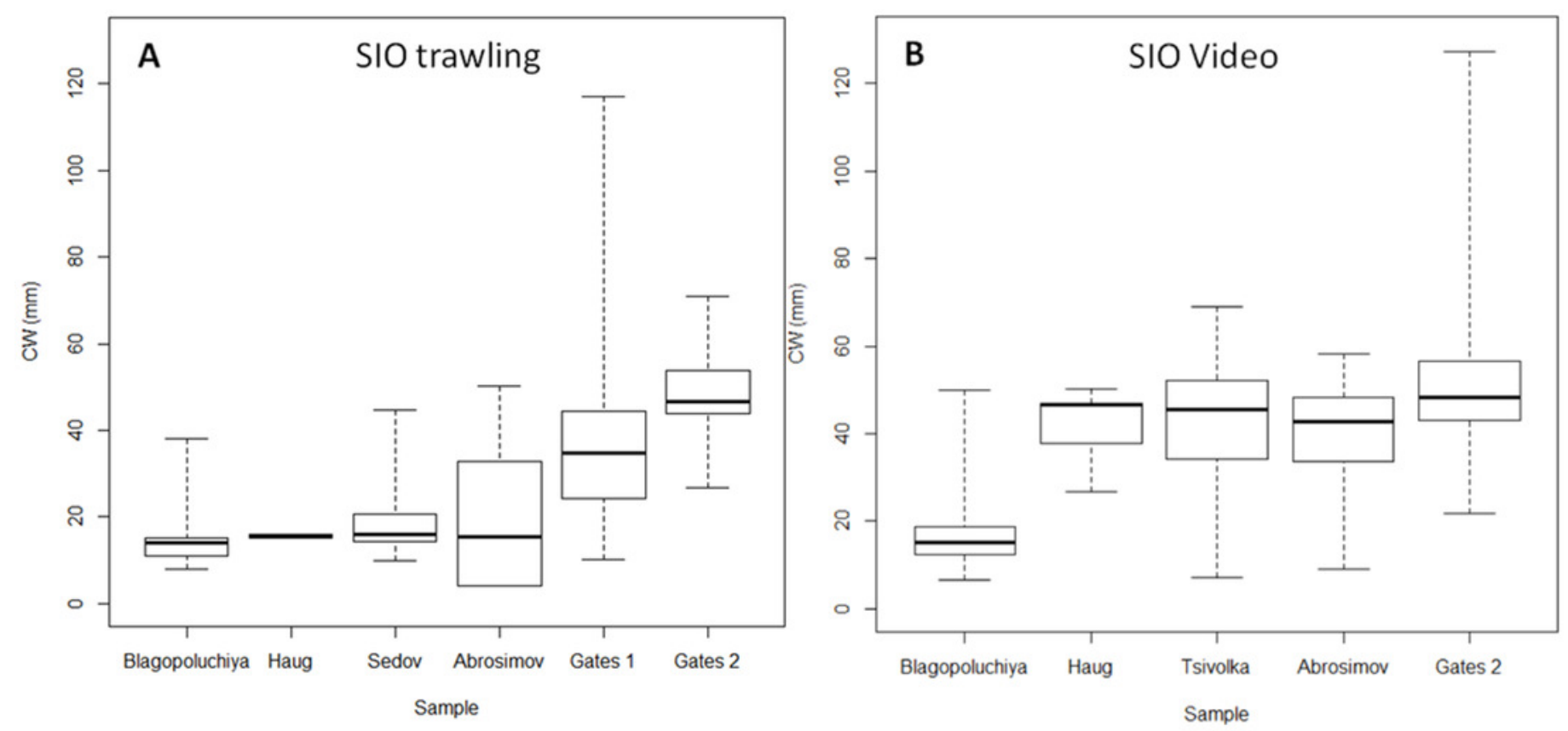
Figure 5

Map of maximum carapace width of Chionoecetes opilio distribution collected using (light grey circles) MMBI bottom and SIO Sigsbee trawling and from (dark grey circles) video footage of the Kara Sea bottom in August-September 2016.

(Map created using PanMap; Grobe et al., 2003) 


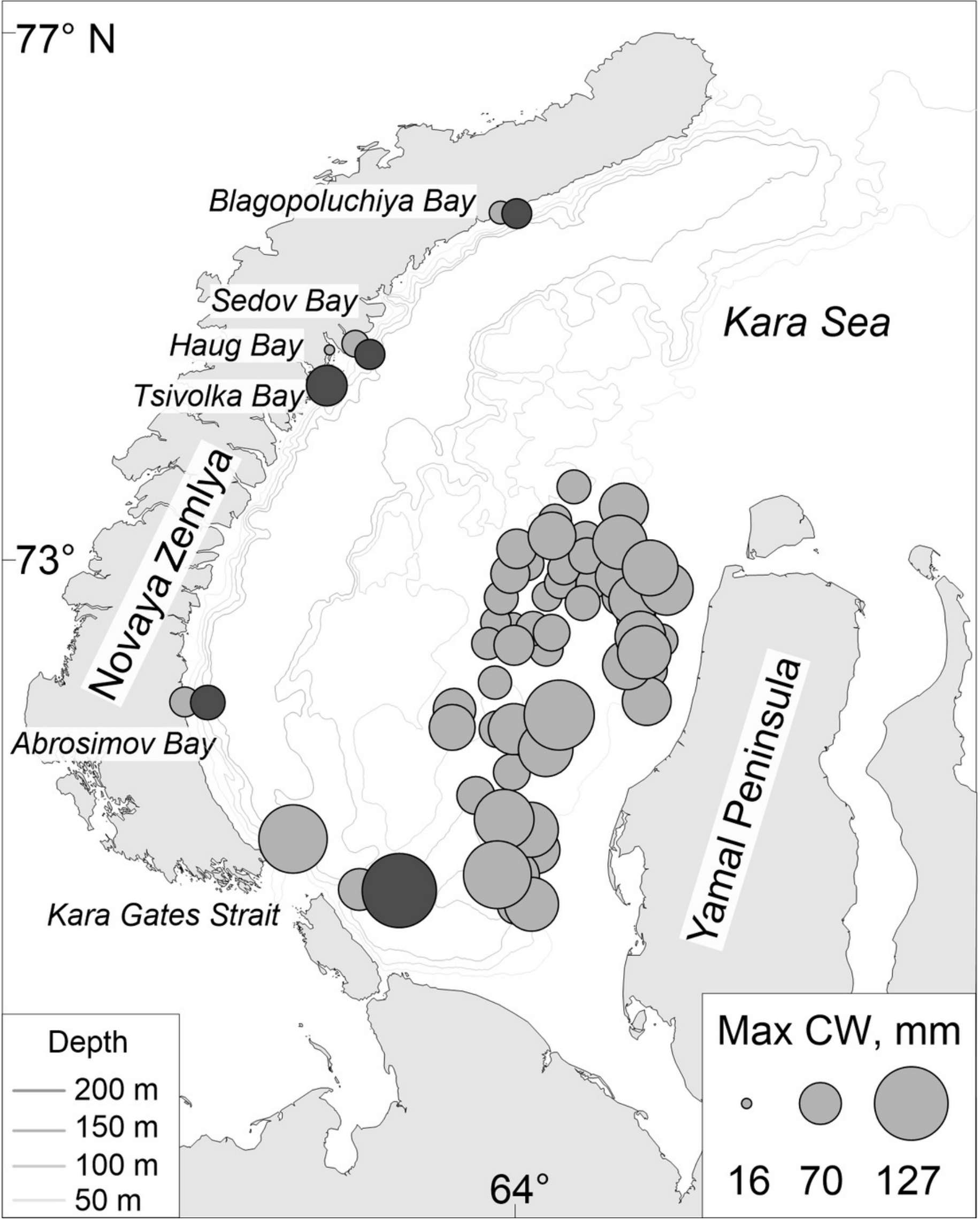


Figure 6

Box plots of carapace width (CW) distribution of Chionoecetes opilio of different sexes.

A. SIO RAS, and B. MMBI trawling samples. $\mathbf{m}$ - males; $\mathbf{f}$ - non ovigerous females; fov ovigerous females; $\mathbf{j}$ - juveniles with $\mathrm{CW}$ less than $11 \mathrm{~mm}$. Boxes reflect the data between the first and third quartile (50\%), thick line is the median, and whiskers extend to the maximum and minimum CWs (see Table 4).
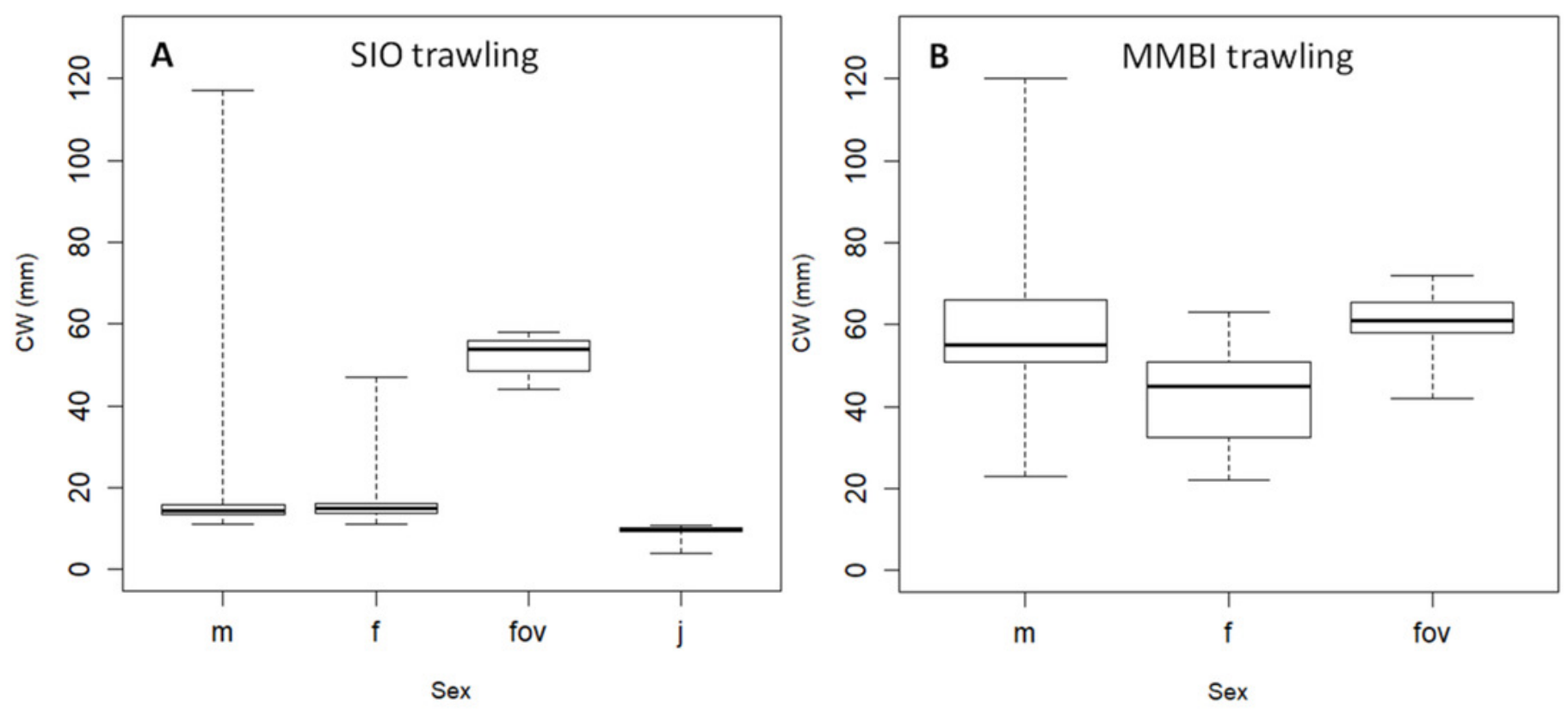


\section{Figure 7}

Frames from the video footage recorded by the UTSI Video module.

A. Blagopoluchiya Bay frame with 8 crabs. B. Imprint of borrowed crab on muddy sediments of Haug Bay. C. A crab creating a sediment cloud while running away in the Kara Gates Straight (filmed in 2017). D. Snow crab in the shadow of a sea lily in Tsivolka Bay. Crosses outline the original position of laser points $60 \mathrm{~cm}$ apart.

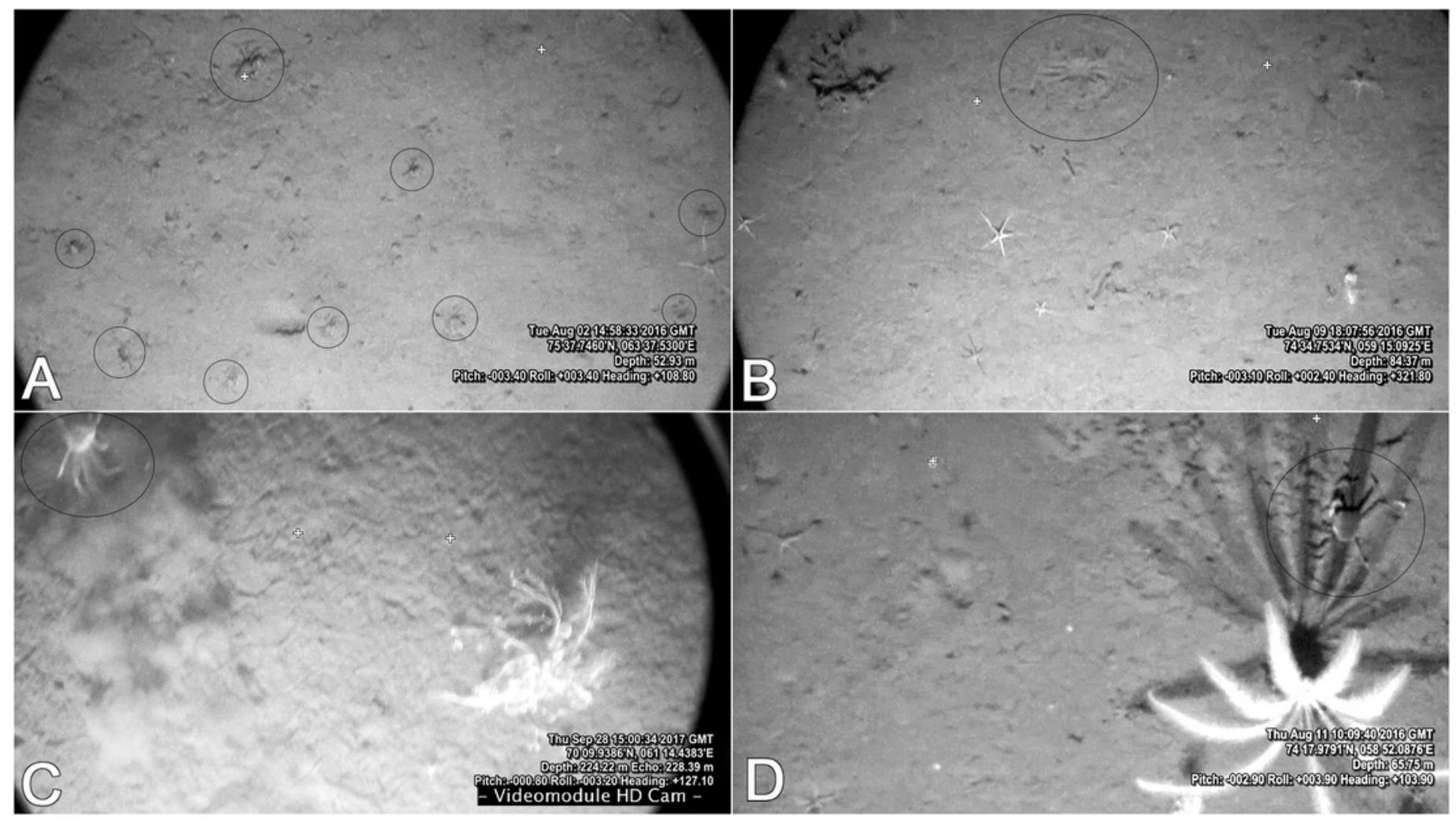

